\title{
Design of Al:ZnO/p-Si Heterojunction Solar Cell Using SCAPS Simulation Program
}

\author{
S.A. Najim¹, K.M. Muhammed ${ }^{2}$, A.D. Pogrebnjak2,"* \\ 1 University of Mosul, Al Majmoaa St., 41002 Mosul, Iraq \\ 2 Sumy State University, 2, Rymsky-Korsakov St., 40007 Sumy, Ukraine
}

(Received 21 March 2021; revised manuscript received 06 August 2021; published online 20 August 2021)

\begin{abstract}
$\mathrm{ZnO}$ thin film is a prominent candidate to be used as a buffer layer in silicon solar cells. In this paper, the effect of $\mathrm{Al}$ concentrations (1, 5, 10 wt. \%) on the conversion efficiency of $\mathrm{Al}: \mathrm{ZnO} / \mathrm{Si}$ thin film solar cells has been investigated through simulation by SCAPS program. It has been found that the main photovoltaic parameters such as open-circuit voltage, short-circuit current density, fill factor, conversion efficiency, quantum efficiency and ideality factor increased as $\mathrm{Al}$ enrichment occurred. At 10 wt. \% of $\mathrm{Al}$ the optimum conversion efficiency was approximately $7 \%$, the maximum value of the ideality factor was 17.51 , and the bandgap value was $3.56 \mathrm{eV}$. Additionally, the resistivity, carrier concentration and mobility were determined for all measurements. It has been found that a decrease in the Hall coefficient led to an increase in the carrier concentration with increasing $\mathrm{Al}$ content, while an increase in the mobility occurred due to a decrease in the electrical resistivity. The quantum efficiency of the solar cell measured at a wavelength in the range of 400-1000 $\mathrm{nm}$ was between 0.4-0.5.
\end{abstract}

Keywords: Al:ZnO thin films, Heterojunction solar cell, SCAPS.

DOI: $10.21272 /$ jnep.13(4).04028

PACS numbers: 42.79.Ek, 78.66.Bz

\section{INTRODUCTION}

Solar cell capacitance simulator SCAPS-3200 is a graphic program for the solar cell simulation developed with LabWindows/CVI of National Instruments at the University of Gent [1]. It is organized in the form of a number of panels and is successfully used for complex modeling the optical and photoelectric properties of solar cells, for instance, $\mathrm{ZnO} / \mathrm{CdS} / \mathrm{CdTe} / \mathrm{CuO}$, Si-CdS$\mathrm{ZnO}, \mathrm{CdS} / \mathrm{CdTe}$ etc. [2-4]. Additionally, it realistically simulates the electrical characteristics of heterojunction solar cells [5]. For example, polycrystalline semiconductor CdTe film and $\mathrm{Cu}(\mathrm{In}, \mathrm{Ga})$ Se solar cell have been modeled by SCAPS to establish the currentvoltage, capacitance-voltage and capacitance-frequency characteristics [6].

A heterojunction solar cell is necessary for the largescale applications in photodetectors and other semiconductors such as silicon, which have a band gap between 1.1 and $1.6 \mathrm{eV}$. It has the potential for higher efficiency, reliability and low cost. A transparent conducting oxide semiconductor is one of the most interesting heterojunction solar cells that includes oxide semiconductors, such as tin oxide $\left(\mathrm{SnO}_{2}\right)$, indium oxide $\left(\mathrm{In}_{2} \mathrm{O}_{3}\right)$ and zinc oxide. Compared to other oxides, it is used more frequently because of its lower cost, good physical, optical and electrical properties, and a large band gap of $3.3 \mathrm{eV}$ [7-9]. Moreover, it is among the most demanded materials for application in TCO because of its abundance in nature, the absence of toxicity, and the ability of the deposited films at low temperatures [8].

\section{EXPERIMENTAL DETAILS}

The schematic structure of the investigated $\mathrm{Al}: \mathrm{ZnO} / \mathrm{Si}$ solar cell is given in Fig. 1 . The $n$-type $\mathrm{ZnO}$ thin film is an intermediate (buffer) layer between $p$-Si absorber layer and $\mathrm{Al}$ metal $p$-type window layer with the main objective to make a good $p$ - $n$ junction.

For the system presented in Fig. 1, we performed five independent SCAPS simulations to study the effect of $\mathrm{Si}$ and $\mathrm{Al}$ layers on $\mathrm{Al}: \mathrm{ZnO} / \mathrm{Si}$ solar cell parameters such as short-circuit current density $\left(J_{s c}\right)$, open-circuit voltage $\left(V_{o c}\right)$, fill factor $(\mathrm{FF})$, conversion $(\eta)$, quantum efficiency $(\mathrm{QE})$, and ideality factor $(n)$. The concentration of aluminium was changed (1, 5 and $10 \mathrm{wt} . \%)$ in order to determine advances of $\mathrm{Al}$ window layer in the investigated solar cell.

From all measurements, the carrier concentration, resistivity and mobility were additionally found. The determination of optimal conditions will lead to the production of transparent, highly conductive and wellcrystallized $\mathrm{ZnO} / \mathrm{Al}$ films.

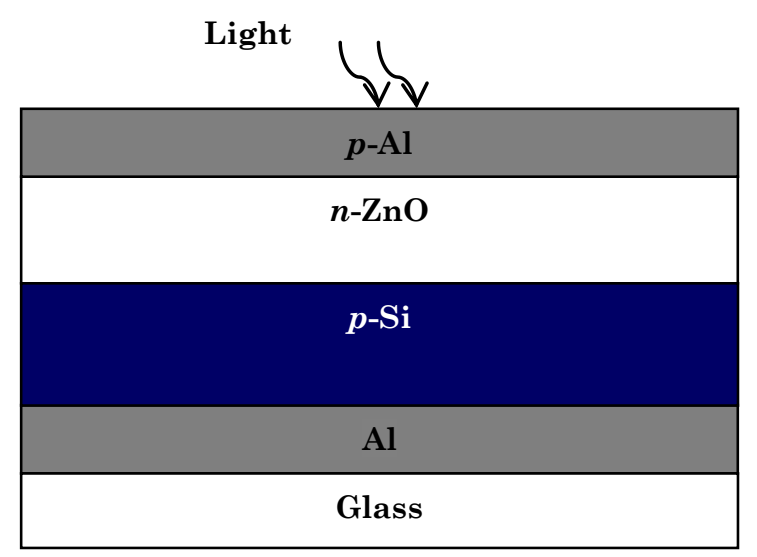

Fig. 1 - Schematic structure of $\mathrm{Al} / \mathrm{ZnO} / \mathrm{Si}$ thin film solar cell

\section{RESULTS AND DISCUSSION}

Fig. 2 presents the dependences of the carrier concentration and band gap on the $\mathrm{Al}$ content in $\mathrm{Al}: \mathrm{ZnO} / \mathrm{Si}$ solar cell. It is obvious that when $\mathrm{Al}$ concentration in-

\footnotetext{
*alexp@i.ua
} 
creases, the carrier concentration also linearly increases due to the decrease in the Hall coefficient. A similar tendency occurs for the band gap. The maximum value of the band gap of $3.56 \mathrm{eV}$ is obtained for $10 \mathrm{wt} . \% \mathrm{Al}$, which is $2 \%$ higher than for 5 wt. $\% \mathrm{Al}$ and $5 \%$ higher than for $1 \mathrm{wt} . \% \mathrm{Al}$. The obtained values of the band gap are in good agreement with the already established value of $3.35 \mathrm{eV}$ reported in $[10,11]$.

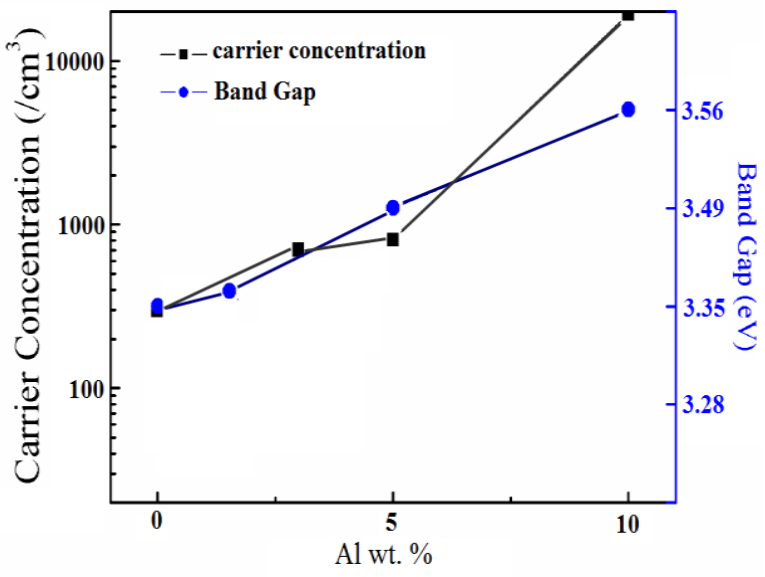

Fig. 2 - Variation of the carrier concentration and band gap with $\mathrm{Al}$ content

The electrical resistivity was calculated using a standard four-point probe method at a distance of $s=2 \mathrm{~mm}$ according to the following equation [12]:

$$
\rho_{m}=2 \pi s(V / I) \text {. }
$$

Fig. 3 shows the dependences of the electrical resistivity and mobility on the $\mathrm{Al}$ content in $\mathrm{Al}: \mathrm{ZnO} / \mathrm{Si}$ solar cell. It is defined that the electrical resistivity decreases to $4.8 \times 10^{-3} \Omega . c m$ as $\mathrm{Al}$ concentration increases to 10 wt. \%. This is due to the replacement of $\mathrm{Al}$ at zinc sites in the hexagonal lattice or isolation of $\mathrm{Al}$ into a homogeneous region at the grain boundary. When doped with $\mathrm{Al}$, the formation of $\mathrm{AlZn}$ can be attributed to the influence of the free-carrier concentration in the film; therefore, it has an effect on the resistivity, but not on the $\mathrm{Al}$ boundary.

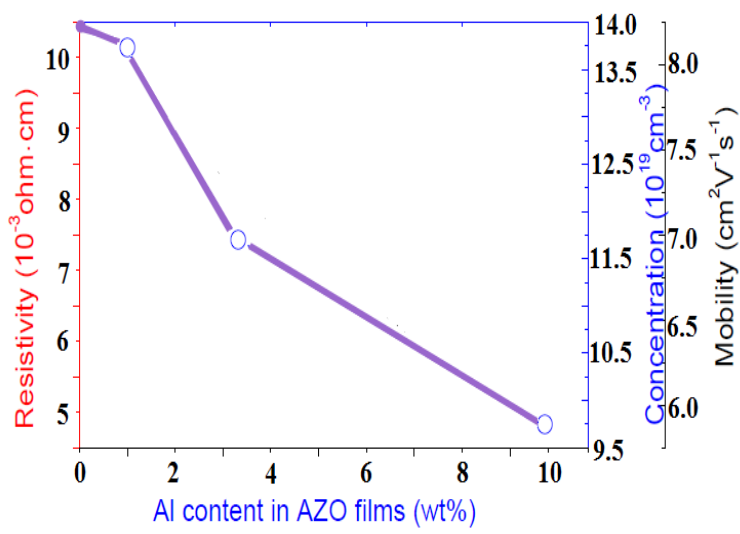

Fig. 3 - Variation of the resistivity and mobility with $\mathrm{Al}$ content

The mobility $\mu$ of the film is determined as

$$
\mu=R H / \rho
$$

where $R H$ is the Hall coefficient and $\rho$ is the resistivity.

The mobility of $\mathrm{Al} / \mathrm{ZnO}$ films increases with increasing $\mathrm{Al}$ content due to a decrease in the resistivity and an increase in the grain boundary scattering (Fig. 3).

Fig. 4 shows the $J-V$ characteristics of the solar cell modeled using SCAPS.

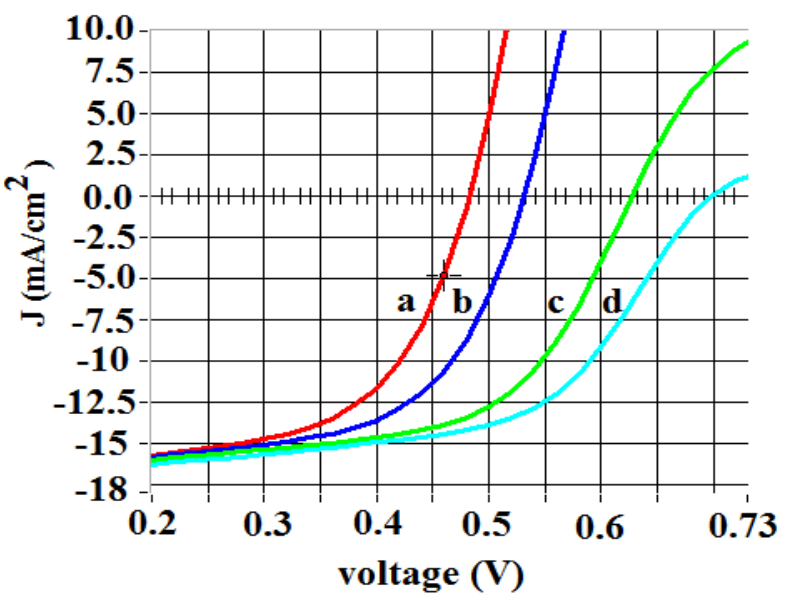

Fig. $4-J-V$ spectra at different $\mathrm{Al}$ content $(1,5,10$ wt. \%) in the solar cell

The fill factor $(\mathrm{FF})$ and efficiency $(\eta)$ of $\mathrm{Al}: \mathrm{ZnO} / \mathrm{Si}$ solar cell are calculated from relations (3) and (4), respectively $[13,14]$ :

$$
F F=\left[\frac{I_{m} V_{m}}{I_{s c} V_{o c}}\right] \times 100 \%,
$$

where $I_{m}$ and $V_{m}$ are the current and voltage obtained at maximum power, respectively.

$$
\eta=\left[\frac{I_{s c} V_{o c} F F}{P_{h v}}\right] \times 100 \%,
$$

where $I_{s c}$ is the short-circuit current, $V_{o c}$ is the opencircuit voltage, $P_{h v}$ is the power density of the incident radiation.

The ideality factor $(n)$ depending on the voltage is calculated from equation (5) [15]

$$
n(V)=\frac{q V}{k T \ln \left(I / I_{0}\right)},
$$

where $q$ is the electron charge (Coulomb), $k$ is the Boltzmann constant $(\mathrm{J} / \mathrm{K}), T$ is the room temperature, $I_{0}$ is the reverse saturation current calculated from the linear region of the plot between $V$ and $\ln I$.

The solar cell parameters obtained during modeling are presented in Table 1. It is obvious that the values of the solar cell parameters $\left(V_{o c}\right.$ and $\left.J_{s c}\right)$ increase as $\mathrm{Al}$ content increases.

It is observed that the fill factor and efficiency increase with increasing $\mathrm{Al}$ content. The optimum conversion efficiency is about $7.02 \%$ at $10 \mathrm{wt} \%$ of $\mathrm{Al}$ (Fig. 5). In addition, the applied illumination caused an increase in the current amount of the solar cell [16].

In Fig. 6, we can observe that the ideality factor increases in the solar cell from 12.22 with pure $\mathrm{ZnO} / \mathrm{Si}$ to 17.51 with 10 wt. $\%$ of $\mathrm{Al}$, which means that it has a 
maximum value with increasing $\mathrm{Al}$ content. In this study, the obtained high ideality factor is due to the homogeneous distribution of carriers at the interfaces [17] and tunnelling processes [18] because of the interfacial $\mathrm{Al}$-doped $\mathrm{ZnO}$ films.

Table 1 - Solar cell parameters obtained at $\mathrm{Al}$ content of 1,5 and 10 wt. $\%$ by SCAPS modeling

\begin{tabular}{|c|c|c|c|c|c|}
\hline Sample & $\begin{array}{c}V_{o c} \\
(\text { Volt })\end{array}$ & $\begin{array}{c}J_{s c} \\
\left(\mathrm{~mA} / \mathrm{cm}^{2}\right)\end{array}$ & $\begin{array}{c}\mathrm{FF} \\
(\%)\end{array}$ & $\eta(\%)$ & $n$ \\
\hline $\mathrm{ZnO}$ & 0.482 & 16.985 & 59.43 & 4.87 & 12.22 \\
\hline 1 wt. \% Al:ZnO & 0.531 & 16.998 & 60.46 & 5.45 & 13.46 \\
\hline 5 wt. \% Al:ZnO & 0.627 & 17.070 & 60.99 & 6.45 & 15.84 \\
\hline 10 wt. \% Al:ZnO & 0.698 & 17.266 & 61.17 & 7.02 & 17.51 \\
\hline
\end{tabular}

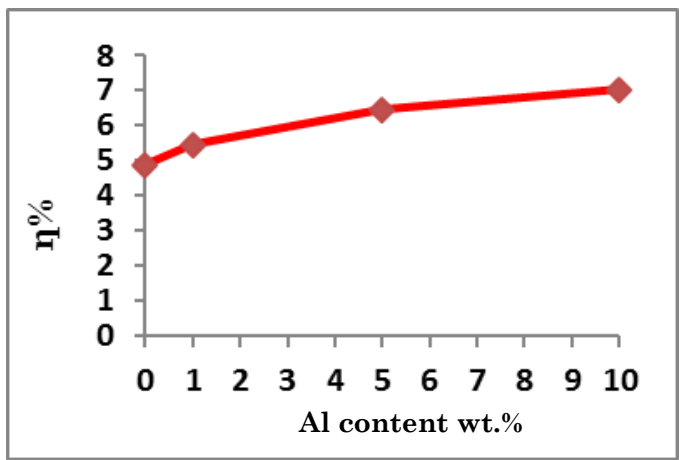

Fig. 5 - Variation of the efficiency as a function of $\mathrm{Al}$ content

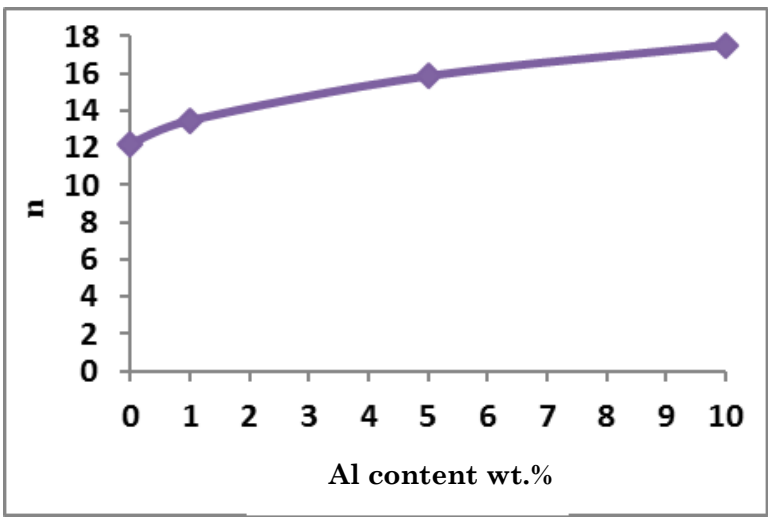

Fig. 6-Variation of the ideality factor as a function of $\mathrm{Al}$ content

\section{REFERENCES}

1. M. Burgelman, J. Verschraegen, S. Degrave, P. Nollet, Prog. Photovoltaics Res. Appl. 2 No 2-3, 143 (2004).

2. Z. Zapukhlyak, L. Nykyruy, G. Wisz, V. Rubish, V. Prokopiv, M. Halushchak, I. Lishchynskyy, L. Katanova, R. Yavorskyi, Phys. Chem. Solid State 21, 660 (2020).

3. N. Jamil, S. Abdulla, A. Muhammed, A. Pogrebnjak, M. Ivashchenko, Proceedings of the International Conference Nanomaterials: Applications and Properties (NAP2012), 1, 04NMEEE09 (2012).

4. N.Y. Jamil, Raf. J. Sci. 26, 133 (2017).

5. J. Verschraegen, M. Burgelman, Thin Solid Films 515, 6276 (2007).

6. M. Bugelman, M. Bugelman, P. Nollet, S. Degrave, Thin Solid Films 361-362, 527 (2000).

7. B. Asenjo, A.M. Chaparro, M.T. Guyerrez, J. Herrero, J. Klaer, Sol. Energy Mater. Sol. C. 87, 647 (2005).

8. X. Zi-qiang, D. Hong, L. Yan, C. Hang, Mat. Sci. Semicon.
The quantum efficiency spectra as a function of the wavelength for different $\mathrm{Al}$ concentrations are shown in Fig. 7. We observe the maximum peak at a wavelength of $640 \mathrm{~nm}$. The plot shows nearly overlap between samples (b) 1 wt. $\% \mathrm{Al}: \mathrm{ZnO}$ and (c) 5 wt. $\% \mathrm{Al}: \mathrm{ZnO}$ at a wavelength of $800-900 \mathrm{~nm}$. At a higher Al concentration (10 wt. \%) (d), the sample absorbs more photons, which increases the overall efficiency of the solar cell.

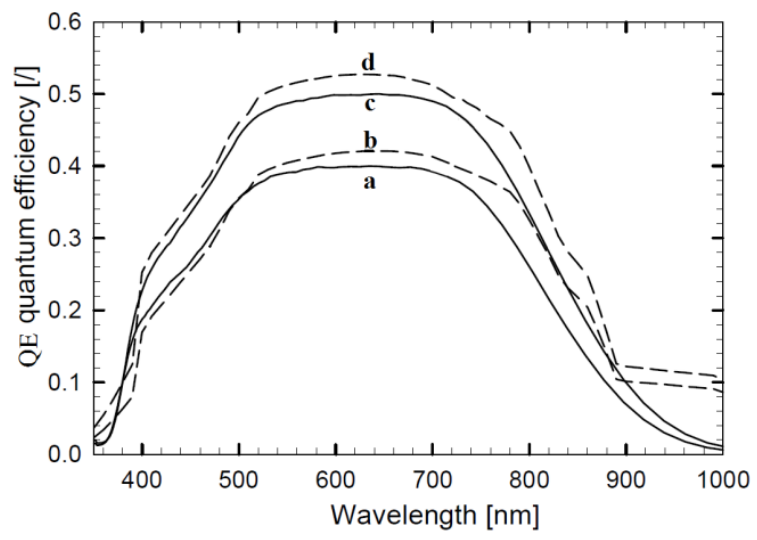

Fig. 7 - Quantum efficiency spectra as a function of wavelength (a - 0 wt. $\% \mathrm{Al}, \mathrm{b}-1$ wt. $\% \mathrm{Al}, \mathrm{c}-5$ wt. $\% \mathrm{Al}, \mathrm{d}-10$ wt. $\% \mathrm{Al}$ )

\section{CONCLUSIONS}

In summary, we have investigated the effect of $\mathrm{Al}$ content (1, 5, 10 wt. \%) on the electrical properties of $\mathrm{Al}: \mathrm{ZnO} / \mathrm{Si}$ solar cell using SCAPS program. It has been established that the band gap increases and reaches $3.56 \mathrm{eV}$ at $10 \mathrm{wt}$ \% of Al. For the sample with $10 \mathrm{wt} . \%$ of $\mathrm{Al}$, a minimum resistivity of $4.8 \times 10^{-3} \Omega$.cm has been obtained. The carrier concentration and Hall mobility of all samples increase with increasing $\mathrm{Al}$ content, but the resistivity decreases. From all measurements, as the $\mathrm{Al}$ content increases to $10 \mathrm{wt} \%$, the efficiency and ideality factor increase to $7.02 \%$ and 17.51 , respectively. The maximum peak for the quantum efficiency for all samples is $640 \mathrm{~nm}$.

Proc. 9, 132 (2006).

9. S.W. Xue, X.T. Zu, W.G. Zheng, M.Y. Chen, X. Xiang, Physics B 382, 201 (2006).

10. S.A. Najim, N.Y. Jamil, K.M. Muhammed, J. Nano- Electron. Phys. 11, 02003 (2019).

11. S.A. Najim, K. M. Muhammed, A.D. Pogrebnjak, IEEE International Conference on "Nanomaterials: Applications \& Properties" (NAP-2020), 01NP04 (2020).

12. F.M. Smits, Bell. Syst. Tech. J. 37, 711 (1958).

13. V.D. Das, L. Damodare, J. Appl. Phys. 81, 1522 (1997).

14. T.J. Coutts, Sol. Energy Mater. 50, 99 (1978).

15. H.C. Card, E.H. Rhoderick., J. Phys D. 4, 1589 (1971).

16. S.A. Najim, J. Basic Education College 15, 3167 (2019).

17. Y.X. Luo, C.H. Shih, Semicond. Sci. Technol. 29, 115006 (2014).

18. J. Lee, T. Uhrmann, T. Dimopoulos, H. Bruckl, J. Fidler, IEEE Trans. Magn. 46, 2067 (2010) 


\title{
Конструювання $\mathrm{Al}: \mathrm{ZnO} / p$-Si сонячного елемента з гетеропереходом за допомогою програми для моделювання SCAPS
}

\author{
С.А. Наджим르. К.М. Мухаммед², О.Д. Погребняк ${ }^{2}$ \\ ${ }^{1}$ University of Mosul, Al Majmoaa St., 41002 Mosul, Iraq \\ ${ }^{2}$ Сумський державний університет, вул. Римського-Корсакова, 2, 40007 Суми, Украйна \\ Тонка плівка $\mathrm{ZnO}$ е потенщійним кандидатом для використання в якості буферного шару в силі- \\ коновій сонячній батареї. У роботі досліджено вплив концентрації $\mathrm{Al}(1,5,10$ мас. \%) на ефективність \\ перетворення сонячних елементів з тонких плівок $\mathrm{Al}: \mathrm{ZnO} / \mathrm{Si}$ за допомогою програми для моделювання \\ SCAPS. Було виявлено, що основні фотоелектричні параметри, такі як напруга розімкнутого ланцю- \\ га, щільність струму короткого замикання, коефіцієнт заповнення, ефективність перетворення, кван- \\ това ефективність та коефіціент ідеальності зростали в міру збагачення плівки $\mathrm{Al}$. При 10 мас. \% Al \\ оптимальна ефективність перетворення становила приблизно 7 \%, максимальне значення коефіціен- \\ та ідеальності складало 17,51, а значення ширини смуги - 3,56 еВ. Крім того, для всіх вимірювань ви- \\ значали питомий опір, концентрацію носія та рухливість. Встановлено, що зменшення коефіцієнта \\ Холла призвело до збільшення концентрації носія із збільшенням вмісту $\mathrm{Al}$, тоді як збільшення рух- \\ ливості відбувалося через зменшення електричного опору. Квантова ефективність сонячного елемен- \\ та, виміряна на довжині хвилі в діапазоні 400-1000 нм, знаходилася в межах 0,4-0,5.
}

Ключові слова: Тонкі плівки $\mathrm{Al}: \mathrm{ZnO}$, Сонячний елемент з гетеропереходом, SCAPS. 